\title{
A comparative study of United States and China exchange rate behavior: A co integration analysis
}

\author{
Khuram Shafi $^{a^{*}}$, Liu Hua ${ }^{\mathrm{b}}$, Javed Altaf Sattic ${ }^{\mathrm{c}}$ and Zahra Idrees ${ }^{\mathrm{d}}$
}

${ }^{a}$ PhD Scholar, School of Management, HuaZhong University of Science and Technology, Wuhan, China

${ }^{b}$ Professor, School of Management, HuaZhong University of Science and Technology, Wuhan, China

${ }^{c}$ Research Scholar, International Islamic university Islamabad, Pakistan

${ }^{d}$ Research Scholar, School of Management, HuaZhong University of Science and Technology, Wuhan, China

\section{H R O N I C L E A B T R A C T}

Article history:

Received September 28, 2014

Accepted 28 December 2014

Available online

January 12015

Keywords:

Exchange rate

International trade

Balance of payment

\begin{abstract}
Exchange rates always affect the prices of the imports and export of products and services in which countries are trading with other parts of the world. Therefore, exchange rate calculation is one of the essential issues for making appropriate policies. This research investigates the determinants of trade, i.e. import, export, industrial growth, consumption level and oil prices fluctuation, which bring changes in exchange rate and their influence eventually on balance of payments. Data of defined variables was collected on yearly basis for China and USA for thirty one years. By applying cointegration, it is estimated that there existed a long run relationship in both countries. USA and China had significant and correct signs on the short run dynamic and some of the factors did not. Exchange rate did not granger cause balance of payment and balance of payment did not granger cause exchange rate. In conclusion, we found that determinants of balance of trade could affect the exchange rates, also, these rates had considerable effect (positive or negative) on balance of payments. In this twofold study, we found relationship of exchange rate with selected determinants of trade, and also examined their bilateral effect, and then made contrast of both countries.
\end{abstract}

\section{Introduction}

Exchange rates are integral part of economic policies' formulation and they are considered as significant tools for measuring the economic health of countries. These rates always affect the prices of the county imports and exports of products and services at which countries are trading to the other parts of the world. They also help in controlling internal and external economic environment of countries. Economic policies play a very pivotal role in setting the direction of economic indicators, the outcomes of these economic policies could affect its balance of trade and its balance of payment in positive direction. Therefore, exchange rate calculation is one of the essentials for policy formulation for countries. According to Qiao, (2007), we are still waiting to have comprehensive theory to predict 
exchange rate depreciation and appreciation on the trade balances, the empirical findings in exchange rate and balance of trade shows the mixed trends (Koray \& McMillin, 2006). Exchange rate is a significant factor in international macroeconomics; its effects have witnessed in the recent past on different currency crises in many economies and has attracted focus of policy makers around the globe. Exchange rate has proved its behavior in determining the country economic position in this age of globalization and trade liberalization. Therefore, this research investigates the determinants of trade i.e. import, export, industrial growth, consumption level and oil prices fluctuation, which bring changes in exchange rate and their influence eventually on balance of payments.

\section{Literature review}

Exchange rate depreciation disturbs the transfer of income between two trading countries, create hindrance in trade provisions and conditions, and hence, upset the economic growth of a country. Despite the academic thoughts about the liaison between real exchange rate and economic growth, it is points out that at theoretical level, such models have been developed which guide the economy to positive or negative effects of variability, and there is no obvious way to characterize the superiority of the models. Similarly, various studies have shown that strong evidence exists among exchange rate and its relationship with country growth (Kim et al., 2004). The prices of goods and services, which are tradable to those non-tradable factors like the exchange rate, play essential role on the country growth and progress. Behavior of Turkish exchange rates within the context of purchasing power parity (PPP) hypothesis was examined by means of recent developments in the panel unit root testing procedures for ten Turkish real exchange rates during January 2002-May 2012.

The unit root test which accounts for nonlinearity, smooth structural shifts, and cross-section dependency supports that PPP hypothesis holds for Euro zone and European countries (Denmark, Norway, Sweden, Switzerland, and United Kingdom), while it does not hold for non-European trading partners (Canada, Japan, Saudi Arabia, and USA). PPP hypothesis holds in the countries which have the free trade agreement, while it is violated in the countries in which there are trade barriers and greater distance. The findings therefore provide policy implications for Turkey in determining equilibrium exchange rates with her major trading partners (Adiguzel et al., 2014). It is found that for most of the 25 sampled floating currencies, excluding the US dollar and euro, there has been a noticeable decrease in the ratio of a currency's distance from the euro to its distance from the dollar during the period from 1999 to 2013. Evidence that exchange risk has increased substantially is also found for dollar-based agents, while it has decreased for euro-based agents. Overall, the findings indicate that the influence of the euro, relative to the dollar, on other currencies has increased since its introduction (Eun et al., 2014).

The possibility of nonlinear adjustment and unknown smooth breaks in the stationarity of real exchange rates in the Group of 20 (G-20) countries over a period from January 1994 to April 2010. The evidence implies that there were nonlinearity and smooth breaks in real exchange rates of G-20 countries (Lee $\&$ Chou, 2013). Hybrid model consisted of macroeconomic fundamentals and market microstructure variables in examining the dynamics of the Uganda shilling/US dollar foreign exchange rates. Utilizing the ARDL framework, they estimated the model using monthly data. Hybrid model was robust to alternative model specifications and provided an adequate framework to explain the dynamics of the Uganda shilling/US dollar foreign exchange rates (Katusiime et al., 2015). By applying an extended vector auto regression model integrating a generalized extreme value distribution to estimate potential losses from investing in the peso/dollar exchange market using daily data for the period 1970-2007; the block maxima approach was applied to minimize the impact from dependency in prices due to the presence of heteroscedasticity. Estimations were presented for short and long positions (de Jesús et al., 2013). The relationships have made similar conclusions between industrial growth, capital goods, investment and consumption level growth as economic growth (Rodrik, 2007). Accordingly, avoiding currency overvaluation is one of the most serious problems; and it is constantly suffering growth process of many countries around the globe (Johnson et al., 2006). 
Furthermore, much of the empirical literature on cross-national policy regressions is now disregarded. But it is maybe just to say that the caution against overvaluation remains as tough as ever (Easterly, 2005). In a survey of international growth literature points that overvaluations create unwanted effects on growth. Summing up, currency overvaluation and undervaluation are creating a challenge for the stable economies to control their stable growth, this need to be catered at very early stage to avoid the disturbance in economic growth and harmful results in long run (Krugman, 1986; McKenzie, 1999; Brada et al., 1997; Hartmann, 1998; Hau \& Rey, 2006). In review of existing literature so far, it is observed that exchange rate plays critical role in international monetary transactions of an economy. Balance of Payments is a summary statement of these international transactions. In other words, balance of payment is used for the accounting of any specific country's total payments made during the certain period of time along with the receipts collected from any other country from private of government exchange sources. Though, studying the relationship between both is quite significant for developing mix of trade reforms, formulation of new trade policies, regulation and restriction for uplifting trade balances to improve balance of payments (Ostry, 1992; Rose, 1989). Hence, making this relationship entirely an empirical issue, and it is suggested that trade liberalization was responsible for disturbance of balance of payment (Nahuis \& Parikh, 2002; Santos-Paulino, 2002; Khan \& Montiel, 1987). Moreover, it is also stated that some countries use dual exchange rates systems because of their weak balance of payments situations, rather than devaluation of their currency, this approach sometime proves costly from a political and social point of view. However, if managed properly this dual exchange rate policy can be valuable for improving balance of payments of developing countries (Obadan, 2002). International trade and foreign exchange markets constancy can be achieved by fixed exchange rates (Cooper et al., 1990). The effect of decrease in imports and increase in exports and eventually balance of payment improvement in long run can be achieved by devaluation. On the contrary, the opinion is that just devaluation does not always improve balance of payments (Kiguel \& Ghei, 1993). The devaluation of currencies of different counties as compared to other currencies also helps in raising the positive balance (Freund \& Pierola, 2008). We have found various studies on determinants of trade i.e. import, export, industrial growth, consumption level and oil prices fluctuation bring changes in exchange rate and its influence eventually on balance of payment but the magnitude, intensity and direction are different because of their complex nature.

\section{Methodology}

Objective of research can be achieved with the help of econometric technique which is used to test the existence of a long run association among the time series of data for China and United States of America. In detail review of literature of exchange rate relationship, the trade balance has significant relationship and economic growth i.e. industrial growth, capital goods and consumption level have strong negative relationship and oil prices have positive/negative relationship with exchange rate as its sign depends upon oil production at national level and its import from other countries.

$$
\begin{aligned}
\text { Exchange rate }= & \beta_{0}+\beta_{1}(\text { Exports })-\beta_{2}(\text { Imp })-\beta_{3}(\text { Capital goods })-\beta_{4}(\text { industrial growth })-\beta_{5} \\
& (\text { Consumption level })+\beta_{6}(\text { Oil prices })+\varepsilon
\end{aligned}
$$

With the help of literature, we concluded that balance of payment and exchange rate have significant relationship with each other. Role of government is very significant in making advantage from this variation with the help of devising country favorable policies for boosting exports and reducing imports helps in their trade reforms, and eventually constructs a strong positive impact on balance of payment.

$$
\text { Balance of payment }=\beta_{0}+\beta_{1}(\text { exchange rate })+\varepsilon
$$

Data of defined variables is collected on annual basis for China and USA. The data of exchange rate (ER) and balance of payment (BOP) are collected from International Financial Statistics (IFS). The data for imports (IM), exports (EX), capital goods (CG) and industrial growth (IG) are taken from 
World Data Bank indicators. Furthermore, Oil prices (OP) (US \$ per barrel) are taken from OANDA forex. All the data are in the same unit as billion US Dollar. We have selected Augmented Dickey-Fuller (ADF) unit root test for this study, with an objective to find out properties before the application of an econometric model. In analyzing the relationship between different time series, some of the variables in different time series may result in non-standard distribution and false regression results. Therefore, for the meaningful results and measurement of long \& short run relationship between data series, our data series should be classified, and variables are called stationary or integrated. With this we can conclude, unit roots problem can be resolved if when stationary of data is attained, then we will become in a position to draw a conclusion with meaningful results (Frankel \& Wei, 2007), similarly, (Maddala \& Kim, 1998) also agreed with the stated notion in his studies regarding the s stationary of data sets for correlation.

Similarly, ADF or unit root test gives us most accurate results in time series analysis. There are many unit root test, DF test is similar to ADF test as long as they both have asymptotic distribution between each other, and other test like Schmidt- Phillips and Phillips-Perronare also used for the same purpose. In this study, we use ADF's of all three types, a) intercept and trend, b) intercept but no trend and, c) no intercept and no trend (Frankel \& Wei, 2007).

Johansen cointegration is used for finding out mutual integration between some groups of nonstationary series, which can result in positive or negative relationship between these groups. Similarly, this is based on finding long term relationship between different variable, hence we have used similar technique. The attraction of cointegration analysis in economics stems from the fact that several key economic relationships, such as the link between income and expenditure or prices and wages, are hypothesized to have long-term, stable relationships. In the literature review, by using Joheanson cointegration procedure in his study for testing relationship among income and energy use in different Asian countries, he also used error-correction analysis in his study (Asafu-Adjaye, 2000). It is conducted that similar kind of technique in testing relationship between the usage of energy and GDP of country in different six of Asian countries including, Singapore, Indonesia, Philippines, Malaysia, India and Pakistan (Masih \& Masih, 1996) The test for a cointegrating relationship provides a means for assessing the nature of this kind of relationship and for assessing the validity of economic theories hypothesizing equilibrium relationships. So, in this study we use the Johansen cointegration test (1991, 1995).After taking the order of stationary at $\mathrm{I}(\mathrm{d})$, this test is used to see whether there is long term relationship exists among the variables. Co-integration test is applied on non-stationary variables to check the long-term equilibrium.

Vector error correction model (VECM) is used in finding the short run relationship between two variables. Long run equilibrium relationship is obtained from the cointergration between two or more series, then to find out behavior properties in short run we use this model. Furthermore, in the case if there is no relationship among the series we do not apply this VECM and we directly proceed to granger causality test to establish causal link between variables. Furthermore, Banerjee (1999) view the error correction mechanism as a useful way of estimating dynamic regression models that incorporate both the long-term focus on levels found in cointegration analysis and the short-term focus on changes found in first-differenced regression models, such as those used (Cantor \& Land, 1985). However, changes in the time series are defined as departures from equilibrium. Regardless of the statistical accounting for these changes in the error correction factor, the dependent variable remains the level of the time series, and the main hypothesis is still one of looking at a stable, long-term relationship and not one of looking at changes in the dependent variable.

Granger Casualty test is used for determining the statistical test hypothesis, Granger Casualty test is used in which one time series forecasting over another. The purpose of Granger Casualty test is to check the short run effect as likewise vector error correction model (VECM) approach. Similarly, in the case, if there is no relationship among the series we do not apply VECM which is stated above and we directly 
proceed to ganger causality test to establish causal link between variables (Box; Johansen, 1988; Johansen \& Juselius, 1990).

\section{Results}

ADF test is applied on level, first and second difference for China and USA. As the null hypotheses time series is non-stationary (unit root). In the Table 2 USA has variables of exchange rate, import, export, industrial growth, capital goods, and consumption level, balance of payment and oil prices are stationary in their second difference I (2).

Table 1

ADF Test (China)

\begin{tabular}{|c|c|c|c|c|c|c|}
\hline Variables & Types of Test & ADF test Statistics & $\mathrm{R}^{2}$ & Stationary & D-W Statistics & Probability \\
\hline$\Delta \Delta$ Exchange Rate & 0 t 0 & $-5.227901^{*}$ & 0.5031 & 2nd Diff & 1.987941 & 0.0011 \\
\hline$\Delta \Delta$ Import & 0 t 0 & $-4.844953 *$ & 0.48123 & 2nd Diff & 1.791541 & 0.0028 \\
\hline$\Delta \Delta$ Export & 0 t 0 & $-4.543969 *$ & 0.45616 & 2nd Diff & 1.516945 & 0.0058 \\
\hline$\Delta \Delta$ Industrial Growth & 0 t 0 & $-4.457721 *$ & 0.45096 & 2nd Diff & 1.687815 & 0.0071 \\
\hline$\Delta \Delta$ Capital Goods & 0 t 0 & $-5.773671^{*}$ & 0.56539 & 2nd Diff & 1.964793 & 0.0003 \\
\hline$\Delta \Delta$ Consumption Level & 0 t 0 & $-4.619584 *$ & 0.44562 & 2nd Diff & 1.922422 & 0.0047 \\
\hline$\Delta \Delta$ Oil Prices & 0 t 0 & $-4.288914^{*}$ & 0.40954 & 2nd Diff & 1.557016 & 0.0102 \\
\hline$\Delta \Delta$ Balance of payment & $0 \mathrm{t} 0$ & $-7.892583 *$ & 0.703 & 2nd Diff & 2.018909 & 0.000 \\
\hline
\end{tabular}

Table 2

ADF Test (USA)

\begin{tabular}{|c|c|c|c|c|c|c|}
\hline Variables & Types of Test & ADF test Statistics & $\mathrm{R}^{2}$ & Stationary & D-W Statistics & Probability \\
\hline$\Delta \Delta$ Exchange Rate & $0 \mathrm{t} 0$ & $-4.403158 *$ & 0.4181 & 2nd Diff & 1.861238 & 0.0078 \\
\hline$\Delta \Delta$ Import & 0 t 0 & $-6.701072 *$ & 0.63551 & 2nd Diff & 1.904336 & 0.000 \\
\hline$\Delta \Delta$ Export & 0 t 0 & $-3.550164 * *$ & 0.31956 & 2nd Diff & 1.967961 & 0.0519 \\
\hline$\Delta \Delta$ Industrial Growth & 0 t 0 & $-3.461655 * * *$ & 0.31316 & 2nd Diff & 1.715187 & 0.0622 \\
\hline$\Delta \Delta$ Capital Goods & 0 t 0 & $-4.285293 *$ & 0.41868 & 2nd Diff & 1.897285 & 0.0106 \\
\hline$\Delta \Delta$ Consumption Level & 0 t 0 & $-4.399164 *$ & 0.44352 & 2nd Diff & 1.818481 & 0.0081 \\
\hline$\Delta \Delta$ Oil Prices & 0 t 0 & $-4.288914 *$ & 0.40954 & 2nd Diff & 1.557016 & 0.0102 \\
\hline$\Delta \Delta$ Balance of payment & c 00 & $-5.05747 *$ & 0.46865 & 2nd Diff & 1.956099 & 0.0003 \\
\hline
\end{tabular}

After taking the order of stationary at $d$ time as $I(d)$, the next step is to apply the cointegration. Since before applying the Johansen cointegration test, lag length is selected. First, we estimate vector autoregressive model and determine the optimal number of lags by ER, IM, EX, IG, CG, CL and OP as endogenous variable. So the optimal numbers of lags for China and USA are one. As the Johansen Cointegration results are shown in Table 3 . In china trace test, 7 cointegration equation(s) at $5 \%$ critical value. These statistics indicates that none null hypothesis is rejected. This means that there were four Cointegration equation $r=7$ among the seven variables at a significance level of $5 \%$. Max-Eigen value test indicates 3 cointegration equation(s) at the 5\% level. For USA, trace test 6 cointegration equation(s) are at $5 \%$ critical value. These statistics indicates that one null hypothesis is rejected as cointegration does not exist. Max-Eigen value test indicates 1 cointegration equation(s) at the $5 \%$ level.

Table 3

Johansen cointegration test results for China

\begin{tabular}{lccccccc}
\hline \multicolumn{2}{c}{ Unrestricted Cointegration Rank Test (Trace) } & \multicolumn{2}{c}{ Unrestricted Cointeg. Rank Test (Maximum Eigen value) } \\
\hline Hypothesized & Trace & 0.05 & & Hypothesized & Max-Eigen & 0.05 & \\
\hline No. of CE(s) & Statistic & Crit.Value & Prob. $^{*}$ & No. of CE(s) & Statistic & Critical & Prob. $^{* *}$ \\
\hline $\mathrm{r}=0^{*}$ & 244.308 & 134.678 & 0.000 & $\mathrm{r}=0^{*}$ & 76.76225 & 47.07897 & 0.000 \\
$\mathrm{r}<1^{*}$ & 167.546 & 103.8473 & 0.000 & $\mathrm{r}<1^{*}$ & 59.69061 & 40.9568 & 0.0002 \\
$\mathrm{r}<2^{*}$ & 107.856 & 76.97277 & 0.000 & $\mathrm{r}<2^{*}$ & 36.99568 & 34.80587 & 0.0269 \\
$\mathrm{r}<3^{*}$ & 70.8604 & 54.07904 & 0.0008 & $\mathrm{r}<3$ & 26.66661 & 28.58808 & 0.0862 \\
$\mathrm{r}<4^{*}$ & 44.19378 & 35.19275 & 0.0041 & $\mathrm{r}<4$ & 19.81693 & 22.29962 & 0.1071 \\
$\mathrm{r}<5^{*}$ & 24.37686 & 20.26184 & 0.0128 & $\mathrm{r}<5$ & 14.72915 & 15.8921 & 0.0754 \\
$\mathrm{r}<6^{*}$ & 9.647706 & 9.164546 & 0.0405 & $\mathrm{r}<6^{*}$ & 9.647706 & 9.164546 & 0.0405 \\
\hline
\end{tabular}


Table 4

Johansen cointegration test results for USA

\begin{tabular}{lccccccc}
\hline \multicolumn{3}{c}{ Unrestricted Cointegration Rank Test (Trace) } & \multicolumn{3}{c}{ Unrestricted Cointegration Rank Test (Maximum Eigen value) } \\
\hline Hypothesized & Trace & 0.05 & & Hypothesized & Max-Eigen & 0.05 \\
\hline No. of CE(s) & Statistic & Critical Value & Prob. ${ }^{* *}$ & No. of CE(s) & Statistic & Critical Value & Prob.** \\
\hline $\mathrm{r}=0^{*}$ & 231.8179 & 134.678 & 0.000 & $\mathrm{r}=0^{*}$ & 83.52201 & 47.07897 & 0.000 \\
$\mathrm{r} \leq 1^{*}$ & 148.2959 & 103.8473 & 0.000 & $\mathrm{r} \leq 1$ & 40.9233 & 40.9568 & 0.0504 \\
$\mathrm{r} \leq 2^{*}$ & 107.3726 & 76.97277 & 0.000 & $\mathrm{r} \leq 2$ & 34.7315 & 34.80587 & 0.051 \\
$\mathrm{r} \leq 3^{*}$ & 72.64111 & 54.07904 & 0.0005 & $\mathrm{r} \leq 3$ & 26.56762 & 28.58808 & 0.0886 \\
$\mathrm{r} \leq 4^{*}$ & 46.07348 & 35.19275 & 0.0023 & $\mathrm{r} \leq 4$ & 21.9523 & 22.29962 & 0.0558 \\
$\mathrm{r} \leq 5^{*}$ & 24.12118 & 20.26184 & 0.014 & $\mathrm{r} \leq 5 *$ & 18.2274 & 15.8921 & 0.0211 \\
$\mathrm{r} \leq 6$ & 5.893783 & 9.164546 & 0.1991 & $\mathrm{r} \leq 6$ & 5.893783 & 9.164546 & 0.1991 \\
\hline
\end{tabular}

In sum, annual data for last 31 years from 1977 to 2008 accomplishes our goal and indicates that there was a long-run relationship between the exchange rate, export, import, industrial growth, capital goods, and consumption level and oil prices in China and USA. From the results generated after the application of test, it is stated that there was a positive and negative relationship of the exchange rate with the import in both countries.

Table 5

Analysis of Exchange Rate and its Determinants of Trade among

\begin{tabular}{lcc}
\hline Variables & USA & China \\
\hline Import & 0.045448 & 0.345106 \\
& {$[+15.7784]$} & {$[+4.13257]$} \\
\hline Export & -0.000889 & -0.190488 \\
& {$[-0.72659]$} & $-3.71844]$ \\
\hline Industrial Growth & 0.016672 & -0.05423 \\
& {$[+4.61438]$} & {$[-0.54956]$} \\
\hline Capital Goods & -0.026658 & 0.242901 \\
& {$[-8.22809]$} & {$[+2.10892]$} \\
\hline Consumption Level & -0.010043 & -0.121547 \\
& {$[-14.7278]$} & {$[-2.25338]$} \\
\hline Oil Prices & -0.091787 & 0.081479 \\
& {$[-8.35701]$} & {$[+1.42935]$} \\
\hline Constant & +29.43777 & +13.94935 \\
\end{tabular}

Export shows the positive effect except China and USA but the impact in export is higher in USA than the China and on the other side the relationship is opposite in both countries for the imports. Industrial goods has negatively related in USA while it is opposite in China. Capital goods has negative coefficient in both countries. Consumption level in both counties has positive relations. Oil price is sensitive in USA and has positive value while the oil price is negatively correlate in China. Negative relationship with exchange rate shows that direction i.e. as it exports increases then currency was appreciated and vice versa if all the variables remain constant then it means equilibrium level has been reached and constant term indicates the long run equilibrium. The intercept value indicates the change in constant change in exchange rate. All the constant term shows significant results.

Table 6

Vector Error Correction Model

\begin{tabular}{clccccccc}
\hline \multirow{4}{*}{ China } & Error Correction: & $\mathrm{D}(\mathrm{ER})$ & $\mathrm{D}(\mathrm{IM})$ & $\mathrm{D}(\mathrm{EX})$ & $\mathrm{D}(\mathrm{IG})$ & $\mathrm{D}(\mathrm{CG})$ & $\mathrm{D}(\mathrm{CL})$ & $\mathrm{D}(\mathrm{OP})$ \\
\cline { 2 - 9 } & CointEq1 & -0.03312 & -0.69574 & -2.53357 & -0.59659 & -0.331 & 0.549076 & -0.46042 \\
& & -0.01763 & -0.61366 & -0.58478 & -0.38788 & -0.42255 & -0.38312 & -0.35841 \\
& & {$[-1.87878]$} & {$[-1.1337]$} & {$[-4.33254]$} & {$[-1.53806]$} & {$[-0.78334]$} & {$[-1.4337]$} & {$[-1.28460]$} \\
\hline \multirow{4}{*}{ USA } & Error Correction: & $\mathrm{D}(\mathrm{ER})$ & $\mathrm{D}(\mathrm{IM})$ & $\mathrm{D}(\mathrm{EX})$ & $\mathrm{D}(\mathrm{IG})$ & $\mathrm{D}(\mathrm{CG})$ & $\mathrm{D}(\mathrm{CL})$ & $\mathrm{D}(\mathrm{OP})$ \\
\cline { 2 - 9 } & CointEq1 & 0.009398 & 2.064497 & 1.6783 & 7.357735 & -4.65128 & -7.71316 & -8.24437 \\
& & -0.01462 & -8.87705 & -6.37147 & -8.99029 & -10.4496 & -12.9521 & -1.4861 \\
& & {$[0.64302]$} & {$[0.2357]$} & {$[0.26341]$} & {$[0.81841]$} & {$[-0.44512]$} & {$[-0.59552]$} & {$[-5.54765]$} \\
\hline
\end{tabular}

Table 6 exhibits the short run vector error correction results. China has significant and correct signs on the short run dynamic and its adjustment is settled in the long run for exchange rate, industrial goods, consumption level, capital goods, oil prices, exports and imports while for short run adjustment in the 
USA for exchange rate, exports and imports and industrial goods are not correctly signed. Capital goods, consumption level and oil prices are correctly signed in short run adjustment for USA.

\section{Table 7}

Granger Causality Test

\begin{tabular}{llcc}
\hline Countries & Null Hypothesis: & F-Statistic & Probability \\
\hline China & ER does not Granger Cause BOP & 0.60358 & 0.44373 \\
& BOP does not Granger Cause ER & 0.01720 & 0.89660 \\
\hline \multirow{2}{*}{ USA } & ER does not Granger Cause BOP & 1.06499 & 0.31091 \\
& BOP does not Granger Cause ER & 0.41410 & 0.52513 \\
\hline
\end{tabular}

In Table 7, granger causality checks the bilateral effect as balance of payment on exchange rate and exchange rate on balance of payment. In China and USA we do not reject the null hypotheses as exchange rate does not cause granger in balance of payment and balance of payment does not granger cause exchange rate as the p-value is greater than $1 \%, 5 \%$ and $10 \%$ significance level. Exchange rate is very important determinant of trading in an open economy. Dealing in foreign exchange market, currency change affects every economy including developed or developing. This occurs because of the market forces of supply and demand, which pushes countries exchange rate as depreciated and appreciated.

\section{Conclusion}

Currently prevailing powers force countries to adopt the planned strategies for their own motives, which are not planned well for development purpose. Therefore, for the macroeconomic stability within a country; economists, policy makers and government should collectively device appropriately matched and synchronized monetary, trade and fiscal policies which stabilize the exchange rate and sustain the balance of payment objectives. It is recommended that it is crucial to have appropriate monitoring systems coupled with suitable macroeconomic policies policy mix for attracting foreign inflow in the markets. Furthermore, these established monitoring at different government levels (i.e. planning commission, State Banks, Ministries like commerce, trade, industries and Custom Department, Bureau of statistics) can act as a supervisory body for the implementation of economic policies. Likewise, for making viable environment for foreign investor consistency must be developed with the international exchange markets, this helps in achievement of reasonable balance of payments goals and for having consistent exchange rates this which will help in long run. In conclusion, we found that determinatnts of balance of trade affect the exchange rates, also, these rates have an considerable effect ( positive or negative) on balance of payments. In this twofold study we found relationship of exchange rate with selected determinants of trade, and also examined their bilateral effect, and then made contrast of both countries. Moreover, apart from the selected determinants of trade, there are many other macroeconomic factors (inflation rates, interest rates, speculation, change in competitiveness, relative strength of other currencies and government debt) and microeconomic factors (political stability position and regional relationship) which may also play role in determination of exchange rates.

\section{References}

Adiguzel, U., Sahbaz, A., Ozcan, C. C., \& Nazlioglu, S. (2014). The behavior of Turkish exchange rates: A panel data perspective. Economic Modelling, 42, 177-185.

Asafu-Adjaye, J. (2000). The relationship between energy consumption, energy prices and economic growth: time series evidence from Asian developing countries. Energy economics, 22(6), 615-625.

Banerjee, A. (1999). Panel data unit roots and cointegration: an overview. Oxford Bulletin of Economics and statistics, 61(S1), 607-629.

Box, G. p. and Jenkins, GM (1976). Time Series Analysis: Forecasting and Control, revised edition: HoldenDay, San Francisco.

Brada, J. C., Kutan, A. M., \& Zhou, S. (1997). The exchange rate and the balance of trade: the Turkish experience. The Journal of Development Studies, 33(5), 675-692.

Cantor, D., \& Land, K. C. (1985). Unemployment and crime rates in the post-World War II United States: A 
theoretical and empirical analysis. American Sociological Review, 317-332.

Cooper, S. D., Walde, S. J., \& Peckarsky, B. L. (1990). Prey exchange rates and the impact of predators on prey populations in streams. Ecology, 1503-1514.

de Jesús, R., Ortiz, E., \& Cabello, A. (2013). Long run peso/dollar exchange rates and extreme value behavior: Value at Risk modeling. The North American Journal of Economics and Finance, 24, 139-152.

Easterly, W. (2005). What did structural adjustment adjust?: The association of policies and growth with repeated IMF and World Bank adjustment loans. Journal of development economics, 76(1), 1-22.

Eun, C. S., Kim, S.-H., \& Lee, K. (2014). Currency competition between the dollar and euro: Evidence from exchange rate behaviors. Finance Research Letters.

Frankel, J. A., \& Wei, S. J. (2007). Assessing China's exchange rate regime. Economic Policy, 22(51), 575-627.

Freund, C., \& Pierola, M. D. (2008). Export surges: The power of a competitive currency.

Hartmann, P. (1998). Currency competition and foreign exchange markets: the dollar, the yen and the euro: Cambridge University Press.

Hau, H., \& Rey, H. (2006). Exchange rates, equity prices, and capital flows. Review of Financial Studies, 19(1), 273-317.

Johansen, S. (1988). Statistical analysis of cointegration vectors. Journal of economic dynamics and control, 12(2), 231-254.

Johansen, S., \& Juselius, K. (1990). Maximum likelihood estimation and inference on cointegration-with applications to the demand for money. Oxford Bulletin of Economics and statistics, 52(2), 169-210.

Johnson, L., Buckley, B., Kocher, P. C., \& Meffert, P. (2006). Routing methods and systems for increasing payment transaction volume and profitability: Google Patents.

Katusiime, L., Shamsuddin, A., \& Agbola, F. W. (2015). Macroeconomic and market microstructure modelling of Ugandan exchange rate. Economic Modelling, 45, 175-186.

Khan, M. S., \& Montiel, P. J. (1987). Real exchange rate dynamics in a small, primary-exporting country. Staff Papers-International Monetary Fund, 681-710.

Kiguel, M. A., \& Ghei, N. (1993). Devaluation in low-inflation economies: The World Bank.

Kim, S.-J., McKenzie, M. D., \& Faff, R. W. (2004). Macroeconomic news announcements and the role of expectations: evidence for US bond, stock and foreign exchange markets. Journal of Multinational Financial Management, 14(3), 217-232.

Koray, F., \& McMillin, W. D. (2006). Fiscal shocks, the trade balance, and the exchange rate. LSU Deparment of Economic Working Paper, 2.

Krugman, P. R. (1986). Pricing to market when the exchange rate changes: National Bureau of Economic Research Cambridge, Mass., USA.

Lee, C.-H., \& Chou, P.-I. (2013). The behavior of real exchange rate: Nonlinearity and breaks. International Review of Economics \& Finance, 27, 125-133.

Maddala, G. S., \& Kim, I.-M. (1998). Unit roots, cointegration, and structural change: Cambridge University Press.

Masih, A. M., \& Masih, R. (1996). Energy consumption, real income and temporal causality: results from a multi-country study based on cointegration and error-correction modelling techniques. Energy economics, 18(3), 165-183.

McKenzie, M. D. (1999). The impact of exchange rate volatility on international trade flows. Journal of economic Surveys, 13(1), 71-106.

Nahuis, R., \& Parikh, A. (2002). Factor Mobility and Regional Disparities: East, West, Home's Best? : CPB Netherlands Bureau for Economic Policy Analysis.

Obadan, M. I. (2002). Exchange Rate Mechanism under the West African Monetary Zone (WAMZ). Central Bank of Nigeria Economic and Financial Review, 40(4).

Ostry, J. a. A. R. (1992). An Empirical Evaluation of the Macroeconomic effects of Tariffs. International Money and Finance, 11, 63-79.

Qiao, H. (2007). Exchange rates and trade balances under the dollar standard. Journal of Policy Modeling, 29(5), $765-782$.

Rodrik, D. (2007). The real exchange rate and economic growth: theory and evidence. Kennedy School of Government manuscript.

Rose, A. K. a. Y., J.L. (1989). Is there a J-curve? Monetary Economics, 24, 53-68.

Santos-Paulino, A. U. (2002). The effects of trade liberalization on imports in selected developing countries. World Development, 30(6), 959-974. 